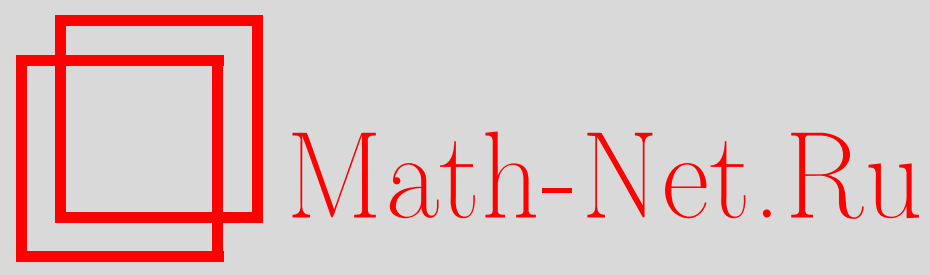

К 90-летию Юрия Ивановича Медведева, Матем. вопр. криптогр., 2019, том 10, выпуск 4, 5-7

DOI: https://doi.org/10.4213/mvk304

Использование Общероссийского математического портала Math-Net.Ru подразумевает, что вы прочитали и согласны с пользовательским соглашением http://www.mathnet.ru/rus/agreement

Параметры загрузки:

IP : 18.208.226.222

26 апреля 2023 г., 10:50:36

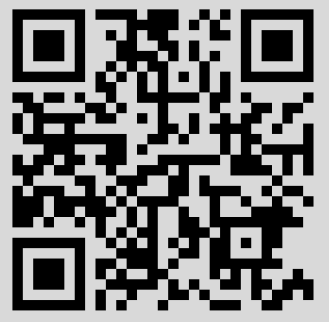




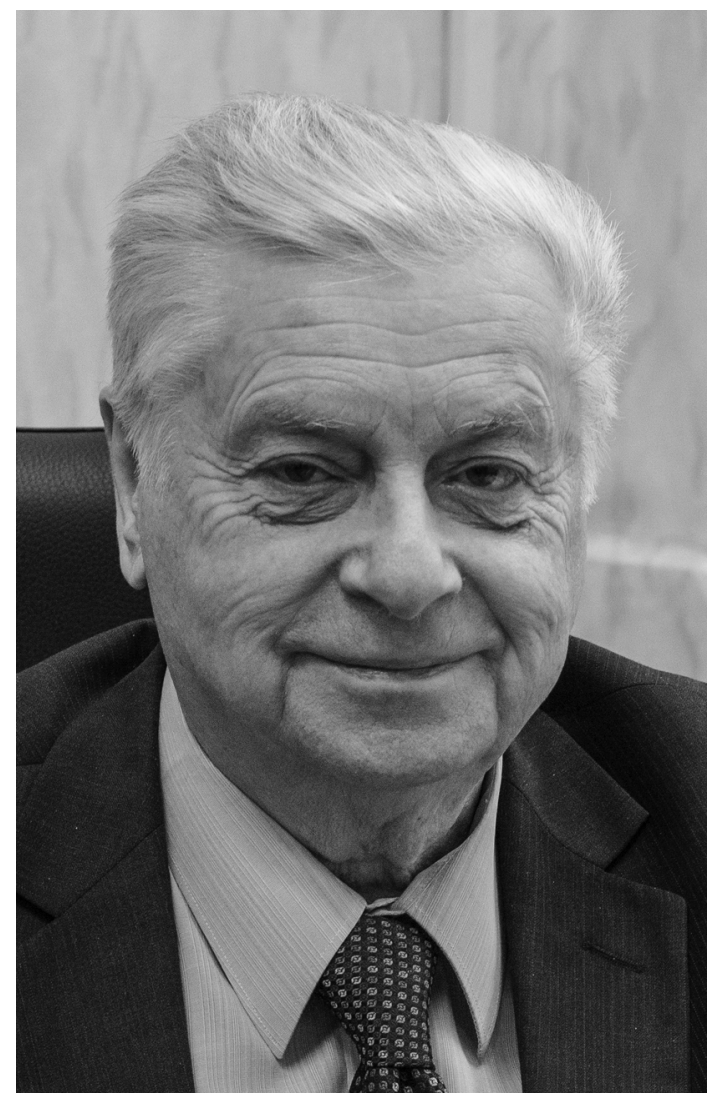

\section{К 90-летию Юрия Ивановича Медведева}

9 декабря 2019 года исполнилось 90 лет со дня рождения видного отечественного математика-криптографа, доктора физикоматематических наук, профессора, действительного члена Академии криптографии Российской Федерации Юрия Ивановича Медведева.

В 1953 году Ю.И. Медведев пришел на работу в Специальную службу после окончания механико-математического факультета МГУ имени М.В. Ломоносова. Он прошел путь от рядового сотрудника до консультанта Главного управления этой Службы. Работа Ю.И. Медведева была связана с решением задач по криптографическому анализу специальной техники. Здесь он успешно использовал возможности вероятностно-статистических методов для решения криптографических проблем и с тех пор занимается их дальнейшей разработкой.

Последующие работы, проводимые возглавляемой им группой криптографов, привели к существенному сдвигу в развитии вероятностно- 
статистических и иных методов криптографического анализа отечественных электронных шифраторов. В руководимом им подразделении были проведены исследования по криптографическому анализу целого ряда отечественных действующих и разрабатываемых электронных шифрсистем. Результаты этих исследований сыграли существенную роль в обеспечении безопасности отечественных линий связи.

Научная деятельность юбиляра включает не только специальную тематику, но и теоретические исследования, отраженные в многочисленных открытых публикациях в ведущих математических журналах вероятностного профиля. Следует отметить, что эти публикации родились из практических задач, возникавших в процессе решения конкретных проблем криптографического анализа электромеханических, электронных и программных шифрсистем.

Областями научных интересов Ю.И. Медведева являются теория вероятностей, математическая статистика, дискретная математика и их приложения. Его основные научные результаты относятся к дискретным проблемам в этих областях: разработке общих методов исследования широкого класса дискретных вероятностных моделей, предельным теоремам для различных типов статистик и случайных процессов в рамках этих моделей, разработке новых статистических критериев, статистических методов оценивания, новых алгоритмов проверки статистических гипотез и исследованию их эффективности, анализу случайных графов, отображений, покрытий и случайных многочленов над конечными полями, спектральному анализу случайных булевых функций.

По результатам этих исследований им написано и опубликовано (лично и в соавторстве с коллегами и учениками) значительное число научных работ, в числе которых более 10 монографий и учебных пособий. В частности, в соавторстве с Г.И. Ивченко подготовлены и изданы книги «Дискретные распределения. Вероятностно-статистический справочник: Одномерные распределения» (2015 г.) и «Дискретные распределения. Вероятностно-статистический справочник: Многомерные распределения» (2016 г.), в настоящее время готовится к выходу в свет монография «Дискретные вероятностные модели». Творческий потенциал юбиляра со временем не ослабевает: он продолжает активную работу над новыми задачами, возникающими в процессе проведения криптографических исследований.

Наряду с производственной и научной деятельностью Ю.И. Медведев много времени и сил уделял преподаванию и подготовке науч- 
ных кадров. Он подготовил и читал оригинальные спецкурсы в ИКСИ и МИЭМе. Им написан в соавторстве ряд учебных пособий по специальности «Прикладная математика» для вузов, среди которых «Математическая статистика», «Задачи с решениями по математической статистике», «Теория вероятностей и математическая статистика в задачах», «Введение в математическую статистику» и др.; эти книги неоднократно переиздавались, а некоторые переведены на иностранные языки.

Юрий Иванович подготовил более десяти кандидатов наук, трое из которых - Г.И. Ивченко, А.Ф. Ронжин, А.П. Баранов - стали докторами наук.

Ю.И. Медведев успешно и плодотворно работает в Академии криптографии Российской Федерации. В период создания Академии он внес большой личный вклад в решение организационных вопросов, в ее становление и развитие, будучи ее первым Главным ученым секретарем. В настоящее время Ю.И. Медведев - член Президиума Академии. Под его непосредственным руководством проведен ряд фундаментальных и прикладных исследований. Он является также членом редколлегий академических журналов «Дискретная математика» и «Математические вопросы криптографии».

Научные достижения и организаторская деятельность Ю.И. Медведева отмечены высокими наградами: орденом Октябрьской Революции, орденом Трудового Красного Знамени, орденом «Знак Почета», званием «Заслуженный деятель науки Российской Федерации», Государственной премией СССР и орденом Почета.

Поздравляя Юрия Ивановича с 90-летием, искренне желаем ему доброго здоровья и новых творческих успехов в его многогранной научной деятельности.

Редакционная коллегия журнала 